\title{
Study on the Development of Furniture-Based Industry Competitive Advantage (Study on Teak Furniture Industry in Southeast Sulawesi- Indonesia)
}

\author{
Mahmudin A. Sabilalo Andi Runis Makkulau \\ Sekolah Tinggi Ilmu Ekonomi Enam Enam Kendari
}

\begin{abstract}
The small wood furniture industry in Southeast Sulawesi Province made a very small contribution to the Gross Regional Domestic Product (GRDP) in 2013-2017, less than 1.00 percent. Where in 2013 amounted to 0.55 percent, in 2014 amounted to 0.49 percent, in 2015 amounted to 0.47 percent, in 2016 amounted to 0.49 percent and in 2017 the contribution of small wood furniture industries to GRDP was 0.48 percent (Source: BPS Sulawesi Tenggara, 2018). The phenomenon of the low contribution of small wood furniture industries to Southeast Sulawesi's GRDP is: (1) The low managerial ability of company owners, (2) The industrial environment in small wood furniture industries is very dynamic when viewed from the strengths of the industry and the low ability of the company. This research aims to measure and analyze the factors causing the teak furniture industry to not develop. Besides that is to produce a model of teak furniture industry development that can create a competitive advantage. The research sample of 143 businessmen teak furniture. Data analysis techniques used are (1) qualitative descriptive analysis through in-depth interviews to get information on the factors that cause the development of furniture-making industry in Southeast Sulawesi Province, (2) Partial Least Square analysis, reinforced by SWOT analysis to obtain information about industrial development models that have a competitive advantage. Results of the research concluded that (1). Factors causing the teak furniture industry that is unable to develop are due to low ability: (a) making business plans, (b) establishing business relationships, (c) the existence of suppliers bargaining power, (d) Threat of substitute products, (e) profit growth which is not optimal yet. (2) The right model for developing the teak furniture industry that can create a competitive advantage is to use the "LIMAPEN" model and implement an aggressive growth strategy.
\end{abstract}

Keywords: industrial development model, teak furniture

DOI: $10.7176 / \mathrm{EJBM} / 13-2-04$

Publication date: January $31^{\text {st }} 2021$

\section{INTRODUCTION}

Small business development has limitations in the ability or resources of companies that can lead to competitive advantage so that it becomes an obstacle in facing competition in the business sector. Specifically, in the Province of Southeast Sulawesi, the slow growth of the industrial sector is due to the wealth of natural resources as an economic potential and the source of raw materials for the industrial sector cannot be utilized optimally.

Small industrial wood furniture in Provincial Southeast Sulawesi contributed very little to the Gross Regional Domestic Product (GRDP) in the year 2013-2017, less than 1,00 percent. Where in 2013 by 0.55 percent, year 20140,49 percent, in 2015 by 0.47 percent, year 20160,49 percent and $2017 \mathrm{k}$ contribute small industry Furniture wood to GDP by 0.48 percent (Source: BPS Sulawesi Tenggara, 2018)

Based on the results of the study (2017) the factors causing the low contribution of small wood furniture industries to the Southeast Sulawesi GRDP are;

1. The low managerial ability of the company owner, which is caused by (a) The formal education level of the company owner is still largely educated from high school to lower. (b) Most of the management knowledge of company owners is still low, especially business planning is done in a short term, unable to make long-term strategic planning, division of tasks in carrying out the work is unclear, lack of direction in the completion of work, and lack of control of activities, so that process activities production is often late. (c) Management skills of company owners are generally low when viewed from the aspect of business development decision making, establishing business relationships with suppliers of raw materials, banks, associations, and customers.

2. The industrial environment in small wood furniture industries is very dynamic when viewed from the strengths of the industry; such as the strength of raw material suppliers, which is marked by the large number of teak logs traded between islands, changes in consumer tastes very quickly, the threat of large companies as newcomers offering furniture products with high quality and design, and the threat of substitute products or furniture products other than wood teak, such as rattan furniture, plastic, aluminum, and other materials.

3. Low capability of the organization/company, caused by (a) Production aspects: generally using less-skilled workers to design products, production process technology is still low, less innovative towards product development, no schedule of completion of activities, and quality control is still lacking, so that production 
activities are inefficient and customer orders are often late. (b) Marketing aspects; generally marketing local products and not understanding about regional and export market opportunities, are not responsive to changes in consumer tastes regarding designs and models (c) Financial aspects: generally still managed conventionally, where no separation between business finance and finance households can cause difficulties to do business financial planning. (d) aspects of human resources; generally there is no proper selection process, the workforce needs are met from family relationships, human resource development is still lacking, especially training in skills and knowledge

That phenomenon can gat important review because the craft industry has long operated wood furniture in Southeast Sulawesi by relying on the comparative advantage of local teak wood raw materials are valuable and rare, it can not provide meaningful added value for the industry wooden furniture. Thus there are indications there are several factors that affect performance the furniture industry wood in Provincial Southeast Sulawesi, namely; company resource factors, industrial environment, and competitive strategy.

It corresponds to research-based resources that do Penrose (1959) that the company's growth is limited by the ability of a manager to coordinate resources. The strategic decision and the right resource selection of the owner/manager in a small company largely determine the company's final performance. Managerial ability is knowledge, skills, and intangible experiences that can be utilized by managers (Hitt et al. 2001).

Resource-based theory shows that company resources must be valuable, rare, unique, and not replicable, which must lead to competitive advantage. The company builds a competitive advantage by utilizing a group of resources classified into three categories; physical or technological capital resources, human capital resources, and organizational capital resources (Barney and Grant, 1991). Furthermore, the resource-based view holds that the condition needed for a company's success is its ability to create special abilities (Teece et al.,1997).

Based on empirical facts and theoretical concepts that have been put forward, it is interesting to study the phenomena that affect the performance of the wood furniture industry in Southeast Sulawesi, resource factors, especially the managerial ability of the businessman or industrial environmental factors that can improve company performance. Based on these reasons, it is interesting to conduct a study by integrating two complementary perspectives, namely the resource-based view and the view of industry organizations in teak furniture small industries in Southeast Sulawesi.

Research this purpose as follows: (1) Knowing the causal factors of industrial furniture of teak wood is not growing (2) Generate a model of the development of industrial furniture of teak wood that can create competitive advantage.

\section{LITERATURE REVIEW}

Research conducted by Adytia and Ratih (2013) concludes that strategies that can be carried out by companies, namely expanding market share, maintaining and improving service quality to customers, using technology, increasing promotion, establishing good relations with suppliers, and recruiting human resources who are competent in their fields. Business development strategy plans are more focused on market development and product penetration. The development of marketing aspects can be done by opening a showroom outside the city while the market penetration strategy that can be done by companies is to increase promotional activities by placing advertisements in newspapers.

Research conducted by Frans (2012) concluded that the marketing performance achieved by the furniture industry respondents in Jepara was in the medium category. This is because the culture-based competitive advantage of furniture industry respondents in Jepara is also included in the medium category. To increase the prominence compete based on culture, carried out by the management of customer knowledge and product differentiation. Where based on the results of the analysis of the index value it is known that the variables of customer knowledge management and product differentiation are included in the medium category.

For variable management of customer knowledge, indicators of gaining knowledge about the customer perceived the lowest by respondents, meaning that industry respondents medium scale in Jepara does not conduct the search, acquire data and information about customers as part of the management of customer knowledge. Whereas from product differentiation variable, indicators on product form-based are perceived to be the lowest by respondents, meaning that respondents of the medium-scale furniture industry in Jepara in producing furniture have not prioritized the original form where one furniture model is still mass-produced and the level of difficulty is still low so very easy for competitors to emulate.

Research conducted by Kuncoro, et al (2010). The characteristic of the furniture industry that needs special attention is the uncertainty of consumer demand because the increase in population does not have a direct impact on the increase in demand for furniture products. Therefore, the policy in conducting production is more difficult to make. The furniture industry is very dependent on the availability of wood supply in conducting production. The decline in the area of natural production forests that support the furniture industry is very influential on the behavior of the furniture industry to keep obtaining raw materials. The activity of importing raw materials and even obtaining wood illegally might be carried out by the furniture industry so that it can continue to produce 
because every year there is an average supply shortage of $3.386 .282 \mathrm{~m}^{3}$ compared to its needs.

The development of the furniture industry still pays little attention to sustainability. Forest destruction is one of the parameters resulting from the activities of the furniture industry and other forest product industries. The rate of decline in the area of natural production forests and overall forests is 61,982 ha and 51,820 ha, respectively. Therefore, there is a need for improvement in management in the supply of raw material sources for the furniture industry, by setting up areas that are used for raw material sources and conducting strict supervision of the activities of extracting raw materials by the industry. In addition to this activity, wood extraction from the forest must be balanced with the replanting of the forest area that is cut down. The Indonesian furniture industry is quite good at meeting consumer needs. However, the revenue that can be achieved by the furniture industry tends not to increase. Further research can be done by developing scenarios that are likely to be applied in the development of the sustainable furniture industry. Other aspects of sustainable development namely economic and social aspects can be analyzed more deeply.

Research conducted by Nasikh (2010) shows that the allocation of the use of production factors of teak furniture small scale business as a whole is not optimal. This is indicated by the existence of a residual value from the factor of labor production. But for the allocation of teak wood production factors and capital is optimal. This means that if the two factors of production are increased it will greatly affect the increase in the income of furniture makers; and combination products meubel are viable and developed by craftsmen in order to gain maximum profit, in general, is 15 tables and chairs, 14 cupboard 1 door, 15 buffets 1 meter, 16 dressers, 12 cupboards 2 doors, 11 buffets 2 meters, 10 wardrobes 3 doors and 9 beds. This means that the combination of furniture products that have been made by craftsmen in Pasuruan is indeed appropriate.

Research conducted by Ida Nuraini (2013) shows the following results: (a) the furniture industry in Malang is mostly concentrated in Blimbing Regency. (b) industrial pottery and ceramics are concentrated in Sukun and Lowokwaru Districts. (c) industry and repair of car shop body concentrated in Blimbing and Klojen Districts. (d) the handicraft industry is concentrated in Blimbing and breadfruit sub-districts. (e) the chemical industry is concentrated in Blimbing and breadfruit sub-districts. (f) the metal industry is mostly concentrated in Sukun and Klojen Districts. (g) the food and beverage industry is concentrated in the Districts of Klojen and breadfruit. (h) furniture industry, textile printing and concentrated in Blimbing and Klojen Districts (i) tobacco industry concentrated in Kedungkandang and breadfruit sub-districts. Based on the analysis of the results shows that the competitiveness of the Malang food and beverage industry has a comparative advantage compared to Malang, Batu, and East Java Province. While the results of the analysis of factors that influence the growth of the industrial sector, the results indicate that capital, the value of raw materials and value-added have a positive effect on manufacturing variable production. The negative variable labor force affects production.

Research conducted by Alfan Himawan and Triwilaswandio Wuruk (2014) found: (1) Not many furniture products for ships have been developed and this is a good business opportunity. (2) Specifications for furniture products for this ship must have the following criteria: a) Construction of ship furniture that can be assembled, b) Use of marine use glue, (3) Furniture design for narrow spaces, (4) Multifunctional furniture.

Types of efficient furniture raw materials for furniture in ship rooms are types of processed wood, such as plywood with specifications: a) The mass is not less than $500 \mathrm{~kg} / \mathrm{m} 3$, b) The wood grain size is not less than B/BB, c) Maximum water content of $14 \%$, d) Thickness of not less than $6.5 \mathrm{~mm}$ and 3 layers of wood. Whereas for certain rooms in the ship such as the kitchen room or machine room and equipment must use raw materials of metal types such as stainless steel or aluminum plates with a thickness of no more than $1.5 \mathrm{~mm}$.

Technical Analysis for the development of ship-specific furniture industry to make it more efficient and productive needs to be implemented several steps, namely: a) Layout and workflow of furniture manufacturing must be organized consisting of processes of material preparation, fabrication, assembly, finishing, checking. b) In the Layout assembly area, the area is divided into 4 concentrations of furniture assembly areas based on the type of furniture (tables, cabinets, chairs, beds). c) Large-scale industrial machine tools for furniture have at least 1 unit of heavy wood machinery including Cross-Cutting Saw Machine, Molding Machine,Planning Machine, Router Machine, Sanding Machine.

Economic Analysis: (a) Based on the condition of the shipping industry for the construction of new ships, ship furniture is much needed and ordered in the last 3 months of the year. In the other 9 months, a replacement product is needed as an alternative product and the sustainability of the ship furniture industry. b) The ship furniture industry can meet at least $60 \%$ of the needs of new building ship furniture in Indonesia per year. c) The total minimum investment value for the ship furniture industry built in the city of Surabaya is $\quad \operatorname{Rp} 2,351,079$, 100.and the investment in the ship furniture industry has reached a break event point (return on investment) for 5 years. From the results of the technical and economic analysis of the development of the supporting industry of ship furniture, it can be assessed that the furniture industry is feasible to be developed in Indonesia.

Research conducted by Adi Permadi (2015), 15 small business units of the Carica industry, where the highest number of units was obtained in Wonosobo District, namely 9 business units. The majority of small-scale Carica industries in Wonosobo Regency are managed by respondents of Carica small-scale industry owners with 
productive age, with the majority of graduates of high school. The majority of Carica's small industrial capital resources in the Wonosobo Regency come from 12 private entrepreneurs. The strength of the Carica small industry in the Wonosobo Regency is the location of the industry which is close to the market. Weaknesses are limited raw materials available.

The opportunity owned by Carica small industries in Wonosobo Regency is the absence of Carica substitution goods on the market. The threat posed by the Carica small industry in Wonosobo Regency is an obstacle during the dry season. Based on the results of research on development strategies that can be carried out by Carica small industries in Wonosobo Regency is a strategy of concentration through horizontal integration. This strategy aims to expand the business by increasing the amount of production and adding services. In the small industry, Carica in Wonosobo Regency can improve product quality and expand markets by way of promotion.

Research conducted by Adhi Prasnowo at.al (2017) concluded: (1) At the Input Stage stage, the input stage obtained data calculations that show the evaluation value of external factors, the value of the business's competitive position compared to business competitors and the evaluation value Internal factors. The EFE value allows SMIs in the production of Desa Terik crackers to be at a very possible level to take advantage of opportunities to minimize existing threats, indicated by a weighting score of 3.69 which means that SMEs are in a responsive condition on a scale of 1-4.

The IFE value shown at 4.09 also indicates that the SMIs in the production of Desa Terik crackers are in a responsive condition to utilize the strength factor as an effort to minimize the weakness factor. From CPM showing the position of the Terik Village crackers as a market leader, the Terik Village crackers can implement strategies by increasing market penetration and market development. (2) At the Matching Stage stage, the formation of a SWOT matrix obtained by strategic alternatives is market penetration, market development, and product development.

At the BCG matrix stage alternative strategies that can be applied include market penetration, market development, and product development. At the Internal Matrix stage - alternative external strategies that can be applied are market penetration, market development, and product development. At the Big Strategy Matrix stage, alternative strategies that can be applied are market penetration, and product development. (3) At the decision stage that is a strategy of "increasing production capacity " in order to meet the increasing market needs, as well as being able to maintain increasingly fierce competition.

Research conducted by Khairul at.al (2015) concluded: Priority strategies resulting from a combination of SWOT and ANP methods are SO Strategies, namely: Providing guaranteed purchases of products produced by the community or SMIs by the government and the government must prepare further processing industries to improve the quality or standards demanded by the market for the products in produce by the community / IKM.

The research conducted by Trifandi (2012) states that there are eleven variables that are worth considering as forming competitive priority models in SMIs in Gorontalo Province. The order of priority is Quality, Cost, Delivery System, Focus on Customers, Flexibility, Ability to Innovate, Market-Oriented, Know-How, Following the Development of Technology, Trade Relations and Support from Government / Private Institutions. From the results of the second stage of data collection and processing, information is obtained that there are ten dominant factors that significantly influence the competitive advantage of SMIs in Gorontalo Province, namely the Delivery System, Customer Focus, Cost of Quality Improvement, Application of New Technology, Flexibility of Production, Quality Products, product attributes, Organizational Structure Lean, Reduction of Disability Products and Product Durability.

Research conducted by Dendi Anggi et al (2014 ) there are four important aspects, namely resources, government regulations, conditions of workers and conditions of demand. Based on the four aspects, the following conclusions are obtained: (1) Of the three most problematic aspects above, then: (a) The highest order of problems in the resource aspect is decreased land fertility, which is then followed by periods the potential of the garden is not optimal and the lack of land intensification. While other problems are relatively smaller, (b) The highest problems in the aspect of government regulation are the lack of local government support, followed by high commercial interest rates, cigarette black campaigns, and less optimal garden management policies, (c) The highest problems in aspects demand conditions, namely changes in overseas consumer preferences. The next problem is the decline in demand from abroad then the lack of domestic consumer preferences for cigars as well as declining overseas consumer purchasing power, (2) Based on the priority of the best solution to increase the competitive advantage of the sustainable business of cigar tobacco in state-owned plantation companies, there are two important aspects that the highest influence in providing solutions that are aspects of resources and aspects of demand conditions, (3) Of the two aspects of the most influential solutions above, then: (a) The highest order of solutions in the resource aspect is optimizing the effectiveness of plantations, intensification of cigar tobacco export. and improvement of technology and infrastructure. While other solutions, namely the use of fertilizer in full, the construction of irrigation networks as well as the increase in adoption and application of technology recommendations have a relatively low value, (b) The highest sequence of solutions in the aspect of demand conditions is the development of products and foreign markets and networking in foreign markets. In addition, 
other solutions are the promotion of periodic and sustainable products, product development and the domestic market as well as increasing the purchasing power of domestic consumers is a solution that has relatively little effect.

Frans Sudirjo (2012) that marketing performance achieved by respondents in the furniture industry in Central Java Province is in the medium category. This is due to the culture-based competitive advantage possessed by the response of the furniture industry den in Central Java Province also included in the medium category. Where based on the results of the analysis of the index value it is known that the variable management of customer knowledge and product differentiation are included in the medium category

For customer knowledge management variables, indicators about acquiring customer knowledge are perceived to be the lowest by the responden, meaning that middle-scale furniture industry respondents in Central Java Province have not conducted the activities of searching, obtaining data and information about their customers as part of customer knowledge management activities. While the variable product differentiation, an indicator of forms-based products perceived as the most despised by the respondents, it means that the respondent industrial furniture medium scale in the province of Central Java in producing furniture has not put form original in which a model of the furniture was mass-produced and the level of the difficulty it is still low, so it is very easy to be emulated by competitors.

From the results of this study, it is known that the marketing performance achieved by the furniture industry respondents in Central Java Province is in the medium category. This is due to the innovation of medium-scale furniture industry products in Central Java Province also in the medium category. To increase product innovation, 206 Frans Sudirjo, Cultural Competitive Advantage, and Product Innovation: An Exploration of Conceptual Models increases competitor knowledge management and research and development intensity, wherefrom the results of a descriptive analysis it is known that the index values for research and development intensity variables and competitor knowledge management are included in the category is on. Of the three indicators used to measure the management of competitors' knowledge, it is known that the indicators of knowledge of competitors are perceived to be the lowest by respondents.

Whereas from the research and development intensity variable, the indicators regarding the relationship between marketing and production are perceived to be the lowest by respondents. From the results of this study, it is known that the marketing performance achieved by the furniture industry respondents in Central Java Province is in the medium category. This is because the culture-based competitive advantage possessed by the mediumscale furniture industry's in the Central Java Province is also included in the medium category. Based on the results of descriptive analysis with the index value shows, of the three indicators used to measure competitive advantage based on culture it is known that the indicator of the level of ease to match has the lowest index value, meaning that the products produced by furniture industry respondents in Central Java Province are very easily imitated by its competitors.

Research conducted by Sudarti at.all (2017) if there is one percent increase in wages there will be a decrease of 0.796 percent of the workforce absorbed in small teak wood processing industries assuming other factors are constant. A decrease in wages means that there is an additional opportunity for labor, which will make the demand for labor higher or increase the total value of elastic production of labor absorption, meaning that if there is one percent increase in production value there will be an increase of 0.962 percent of the energy absorbed in the wood processing industry teak assuming other factors are constant. Increasing the total value of production will increase the amount of labor absorbed in the small teak wood processing industry.

Research conducted by Muhammad Akbar (2017) found: The development strategy that can be applied in the crispy mushroom business of the Oyster Mushroom Processing Industry in Pekanbaru City is in quadrant 1, which is a strategy to support aggressive growth policies. This aggressive strategy is more focused on the SO strategy (strength-opportunities), namely by using the power to take advantage of existing opportunities. The SO strategy ( strength-opportunities ) is: Increasing HR expertise, increasing promotional activities and product diversification.

Mariani (2015) found: Factors that influence the development of the Irma Jaya Rattan Furniture Industry are internal factors and external factors, for internal factors have a total value of 3.61, while the calculation results of the rating value and internal factor weights are 1.57 .

Grand Strategy Matrix based on Internal Factor Analysis Summary (IFAS) analysis which is at the value of 1.57 is on the X-axis, while external factors have a total value of 2.61 and the calculation results of the rating value and the weight of external factors is 1.47. Grand Strategy Analysis Matrix External Factor Analysis Summary (EFAS) is at a value of 1.47 which is used as the horizontal axis or Y-axis.

\section{METHODS}

This research was conducted in the area of Southeast Sulawesi Province, namely in the Muna and Konawe Regencies, with the object of competitive advantage. Manufacture of furniture, in this case, is small-scale industries that grow naturally, then the Department of Industry and Trade of the local set as the object of fostering and facilitating the access to capital to bank financial institutions, including the fostering of business management. 
The unit of analysis in this study is the business owner who is considered to have a direct and responsible role in decision making. The reason for choosing the teak furniture industry is that this business has not yet developed optimally, recorded as many as 143 business units (Disperindag of Southeast Sulawesi Province, 2017).

Determining the location sample in this study using the technique of sampling area in Raha and Unaaha City, with consideration having industrial furniture teak with species and total project a relatively large and are considered representative. Based on the predetermined sample locations, the sample is determined by census, which is to take the entire teak furniture industry in Raha and Unaaha cities recorded in Disperindag to become samples. Thus, the respondents of this study were 143 business operators distributed in Raha City as many as 92 business units, Unaaha as many as 51 business units.

This research used a technique Collecting the data as follows : (1) Questionnaire (2) In-depth interviews. Data analysis techniques in this research as follows : (1) analysis qualitative description (2) analysis quantitative with tools PLS Smart program, then in the elaboration by the results to produce a model that can be implemented in order to create a competitive advantage. Besides that, it was strengthened by SWOT analysis.

\section{RESULTS}

\section{Characteristics of Teak Furniture Industry Players}

The characteristics of the teak furniture industry in this research are the individual characteristics of each respondent observed in terms of age, education level and family members. Based on the results of the study the characteristics of teak furniture industry players are shown through the following Table 1:

Table 1. Respondents in Teak Furniture Industry Based on Individual Characteristics

\begin{tabular}{|c|c|c|c|}
\hline \multicolumn{2}{|c|}{ Age (years) } & \multirow{2}{*}{$\begin{array}{c}\begin{array}{c}\text { Number of Respondents } \\
\text { (Person) }\end{array} \\
11\end{array}$} & \multirow{2}{*}{$\begin{array}{c}\begin{array}{c}\text { Percentage } \\
(\%)\end{array} \\
7.69\end{array}$} \\
\hline 1 & $31-34$ & & \\
\hline 2 & $35-38$ & 16 & 11.19 \\
\hline 3 & $39-42$ & 27 & 18.88 \\
\hline 4 & $43-46$ & 51 & 35.66 \\
\hline 5 & $47-50$ & 21 & 14.69 \\
\hline 6 & $51-54$ & 9 & 6.29 \\
\hline 7 & $55-58$ & 8 & 5.59 \\
\hline \multicolumn{4}{|c|}{ Level of education } \\
\hline 1 & Elementary School & 11 & 7.69 \\
\hline 2 & SLTP & 13 & 9.09 \\
\hline 3 & SLTA & 96 & 67.13 \\
\hline 4 & DIPLOMA & 9 & 6.29 \\
\hline 5 & $\mathrm{~S} 1$ & 14 & 9.79 \\
\hline \multicolumn{4}{|c|}{ Family Member (person) } \\
\hline 1 & $1-2$ & 42 & 29.37 \\
\hline 2 & $3-4$ & 90 & 62.94 \\
\hline 3 & $5-6$ & 11 & 7.69 \\
\hline \multicolumn{2}{|c|}{ Amount } & 143 & 100.00 \\
\hline
\end{tabular}

Source: Primary data, 2019.

\section{Business Characteristics}

The characteristics of the teak furniture industry business in this research are the pioneering time of the business, the number of workers, the source of labor, the origin of the business, and the source of capital. Based on the results of the study, the characteristics of the teak furniture industry are shown in the following Table 2: 
Table 2. Respondents in Teak Furniture Industry Industry Based on Business Characteristics

\begin{tabular}{|c|c|c|}
\hline Length of Starting a Business (Year) & $\begin{array}{c}\text { Number of Respondents } \\
\text { (Person) }\end{array}$ & $\begin{array}{c}\text { Percentage } \\
(\%)\end{array}$ \\
\hline $3-5$ & 73 & 51.05 \\
\hline $6-8$ & 38 & 26.57 \\
\hline $9-11$ & 21 & 14.69 \\
\hline $12-14$ & 3 & 2.10 \\
\hline $15-17$ & 4 & 2.80 \\
\hline $18-20$ & 3 & 2.10 \\
\hline $7 \quad 21-24$ & 1 & 0.70 \\
\hline \multicolumn{3}{|l|}{ Labour (People) } \\
\hline $11-4$ & 106 & 74.13 \\
\hline $25-19$ & 37 & 25.87 \\
\hline \multicolumn{3}{|l|}{ Labour Resources } \\
\hline 1 Family (wife/children) & 22 & 15.38 \\
\hline Kin & 34 & 23.78 \\
\hline 3 Not a family/relative & 87 & 60.84 \\
\hline \multicolumn{3}{|l|}{ The Origin of the Business } \\
\hline $1 \quad$ Built alone & 139 & 97.20 \\
\hline Inherited parents & 3 & 2.10 \\
\hline $3 \quad$ Other (collaboration) & 1 & 0.70 \\
\hline \multicolumn{3}{|l|}{ Capital Resources } \\
\hline 1 Personal Savings & 107 & 74.83 \\
\hline Savings + Sharia Bank & 12 & 8.39 \\
\hline Savings + Conventional Bank & 18 & 12.59 \\
\hline $4 \quad$ Savings + Non-bank loans & 6 & 4.20 \\
\hline Amount & 143 & 100.00 \\
\hline
\end{tabular}

Source: Primary data, 2019.

3. Competitive Advantage Variable

Competitive Advantage in this research is the ability of teak furniture business to achieve profits above the industry average profit observed from the indicator: reduce costs lower than competitors, produce products with cost-efficient, improve service to customers, create different products, focus on certain customers and focus on certain market segments. Based on the results research, descriptive perceptions of business operators on competitive advantage in the show through the following Table 3:

Table 3. Description of Competitive Advantage Variables

\begin{tabular}{llcc}
\hline \multirow{2}{*}{ Variable } & Indicator & \multicolumn{2}{c}{ Average Indicator } \\
& Pressing costs lower than competitors & Indicator & Variable \\
\hline & Cost-efficient products & 3.23 \\
Competitive & Improve customer service & 3.14 \\
Advantage & Creating different products & 4.09 & 3.33 \\
& Focus on specific customers & 3.13 & \\
& Focus on certain market segments & 3.18 & \\
\hline
\end{tabular}

Source: Primary data, processed in 2019.

Based on the data description of respondents' perceptions of competitive advantage, it can be known that teak furniture businesses have a less competitive advantage when observed from indicators. Reducing costs lower than competitors, Products with cost-efficient, Creating different products, Focusing on specific customers, Focusing on segments Certain markets are marked with a variable average score of 3.33.

\section{Description of Managerial Capabilities}

Managerial ability is a set of competencies owned by teak furniture entrepreneurs as business owners consisting of; education, experience, and expertise, both conceptual expertise, human relations skills, as well as technical expertise in carrying out company functions observed from the indicators: making business plans, building workgroups, moving employees, establishing business relationships and conducting supervision. Based on the results of the study, descriptively the perception of business actors towards the industrial environment is shown through the following Table 4: 
Table 4. Description of Managerial Ability Variables

\begin{tabular}{|c|c|c|c|}
\hline \multirow{2}{*}{ Variable } & \multirow{2}{*}{ Indicator } & \multicolumn{2}{|c|}{ Average } \\
\hline & & Indicator & Variable \\
\hline \multirow{5}{*}{ Managerial Ability } & Make a business plan & 3.13 & \multirow{5}{*}{3.69} \\
\hline & Building a workgroup & 4.06 & \\
\hline & Moving employees & 4.02 & \\
\hline & Establish business relations & 3.14 & \\
\hline & Supervise & 4.10 & \\
\hline
\end{tabular}

Source: Primary data, processed in 2019.

Based on the data description of respondents' perceptions of managerial ability, it can be known that teak furniture industry players have managerial abilities with poor categories when observed from indicators of ability to make business plans and establish business relationships, which are indicated by an average score of 3.69 variables.

\section{Description of environment Industry}

The industrial environment in this study is the condition of uncertainty and intensity for teak furniture business actors observed from the indicators: the threat of new entrants, the bargaining power of suppliers, the threat of substitute products, the bargaining power of buyers, the intensity of competition in the industry. Based on the results of the study, descriptively the perception of business actors towards the industrial environment is shown through the following Table 5:

Table 5. Description of Industrial Environment Variables

\begin{tabular}{llcc}
\hline Variable & Indicator & $\begin{array}{c}\text { Average } \\
\text { Indicator }\end{array}$ & Variable \\
\hline \multirow{4}{*}{ Industrial } & The threat of new company entrants & 4.06 & \\
environment & Bargaining power of suppliers & 3.15 & 3.71 \\
& The threat of substitution products & 3.14 & \\
& Bargaining power of buyers & 4.08 & \\
& The intensity of competition in the industry & 4.13 & \\
\hline
\end{tabular}

Source: Primary data, processed in 2019.

Based on the data description of respondents 'perceptions of the industrial environment, it can be known that teak furniture industry players do not know the industrial environment when observed from suppliers' bargaining power indicators and the threat of substitute products marked by an average variable score of 3.71 .

\section{Company Capability Variables}

The company's ability in this study is the level of attainment of business teak furniture in a certain time period that was observed in the indicators: growth results of sales, growing earnings and asset growth. Based on the results of the study, perceptions of business operators regarding business capability variables are shown in the following table:

Table 6. Perception of business capability variables

\begin{tabular}{clcc}
\hline \multirow{2}{*}{ Variable } & \multicolumn{1}{c}{ Indicator } & \multicolumn{2}{c}{ Average Indicator } \\
& & 4.12 & Variable \\
\hline \multirow{3}{*}{ Business ability } & Growth in sales results & 3.14 & \multirow{2}{*}{3.79} \\
& Profit growth & 4.11 & \\
\hline
\end{tabular}

Source: Primary Data, 2019

Based on the data description of respondents' perceptions of business ability, it can be known that teak furniture business operators do not know the industry environment well when observed from profit growth indicators.

\section{Model Testing}

Based on research data obtained the following results: 


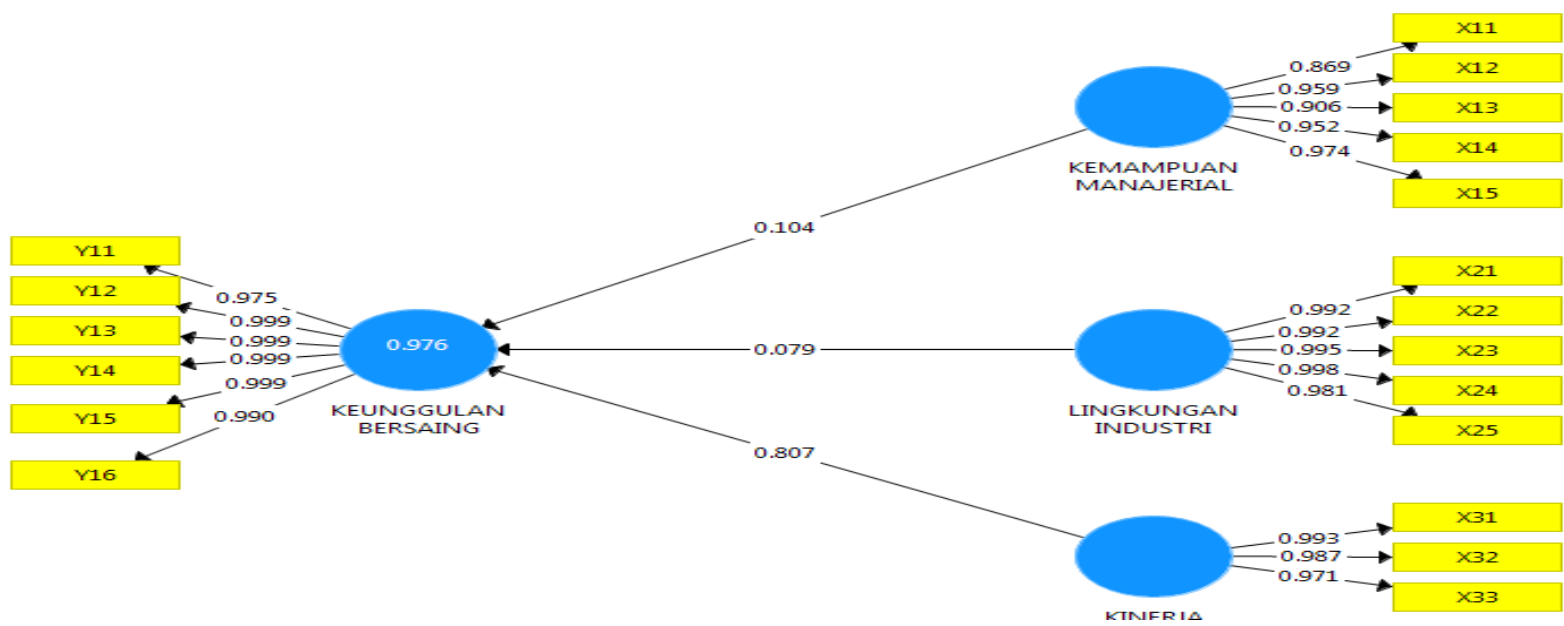

Notes:

Figure 1 . Full Model Increasing Competitive Advantage

Keunggulan Bersaing = Competitive Advantage

Lingkungan Industri = Industrial Environment

Kinerja Usaha $\quad=$ Company performance

Table 7. Path Coefficients

\begin{tabular}{|c|c|c|c|c|c|c|}
\hline \multicolumn{2}{|l|}{ Direct Effect } & $\begin{array}{c}\text { Original } \\
\text { Sample } \\
\text { (O) }\end{array}$ & $\begin{array}{c}\text { Sample } \\
\text { Mean } \\
\text { (M) }\end{array}$ & $\begin{array}{l}\text { Standard } \\
\text { Deviation } \\
\text { (STDEV) }\end{array}$ & $\begin{array}{l}\text { T Statistics (| } \\
\text { O / STDEV |) }\end{array}$ & p- values \\
\hline \multicolumn{2}{|l|}{$\begin{array}{l}\text { Managerial Ability } \\
\text { Competitive Advantage }\end{array}$} & 0.104 & 0.069 & 0.077 & 1.347 & 0.179 \\
\hline $\begin{array}{l}\text { Industrial Environment } \\
\text { Competitive Advantage }\end{array}$ & Against & 0.079 & -0.178 & 0.913 & 0.087 & 0.931 \\
\hline $\begin{array}{l}\text { The Company's ability to } \\
\text { excellence }\end{array}$ & pete for & 0.807 & 1.100 & 0.935 & 0.863 & 0.389 \\
\hline
\end{tabular}

Source : Primary data, 2019

\section{Discussion}

1. Cause of Teak Furniture Industry That Doest Not Have Competitive Advantage.

Based on research results, teak furniture industry does not have a competitive advantage that can be observed through the following indicators:

a. Not able to reduce production costs to be lower than competitors. This means that business actors do not know how to do production at a low cost, not yet maximally inviting employees to produce at an efficient cost, the business has not fully experienced production cost efficiency in the last three years.

b. Not able to produce cost-effective products. This means that businesses do not fully know how to produce products that are cost-efficient, lack of teaching employees to make products that are cost-efficient, teak furniture products that produce less cost-efficient.

c. Not able to produce different products from competitors. This means that businesses do not fully know how to differentiate products, do not teach employees of teak furniture production techniques that have competitive advantages, teak furniture products produced lack superior variations.

d. Not yet focused on certain customers. This means that businesses do not fully understand how to serve certain customers, do not teach employees how to make product variations for certain customers, no teak furniture products produced are specific to certain customers such as officials.

e. Not yet focused on certain market segments. This means that businesses do not fully understand how to enter certain market segments, do not teach employees how to make products for certain market segments. Besides that, there is no teak furniture product produced for certain market segments such as offices

Factors that cause the teak furniture industry to not have a competitive advantage are:

a. The ability to make a low business plan. In this case business plans made by business actors are not well understood by employees, business plans are implemented less responsibly by employees and business actors have not taken strict action for employees who do not implement the business plans that have been set.

b. The ability to establish business relationships is not good. In this case, business actors do not fully know how 
to establish a good relationship with consumers or business partners, not yet optimal in maintaining good business relationships with anyone, especially consumers and less expanding business relationships with profitable parties.

c. The bargaining power of suppliers in its implementation is anticipated to be unfavorable. This means that business actors do not know that suppliers have the bargaining power to the needs of raw materials needed, have not actively monitored the bargaining power of suppliers, and have not made suppliers as partners in business.

d. The threat of product substitution less than anticipated by either. This means that actors do not fully understand the existence of substitute products (aluminum furniture, rattan, coconut stems) that can reduce market share, have not fully followed the business development of substitute products, and do not make subproducts as business partners.

e. Profit growth is not good, because business actors do not fully know how to obtain optimal profits, not yet optimal in utilizing employees to work together in earning profits.

\section{Application of Model Right To Development Teak Furniture Industry Can Create Competitive} Advantage.

Applying the right model for the development of teak furniture industry that can create a competitive advantage is to use the "LIMAPEN" model, namely:

a. Increased ability to make business plans. The trick is : (a) encourage employees to jointly create a business plan, (b) oversee the implementation of the business plan in order to implement full responsibility, (c) take decisive action on irregularities implementation of the plan.

b. Increased ability to establish business relationships. The trick is: (a) establishing a partnership with business partners including consumers. (b) Maintain and expand partnership relationships with anyone who can benefit.

c. Increasing partnerships with many suppliers of raw materials. The trick is: (a) not only depend on one supplier, (b) Make the supplier a partner in the business.

d. Increased awareness of the threat of substitute products. The trick is (a) following the development of the existence of substitute products such as aluminum furniture, rattan, coconut trunks) can reduce market share, have not fully followed the business development of substitute products, and do not make the substitution products as business partners.

e. Profit growth is not good, because business actors do not fully know how to obtain optimal profits, not yet optimal in utilizing employees to work together in earning profits.

For give out a strengthening of the analysis were used SWOT approach is to analyze the internal strengths and weaknesses as well as externally analyze the opportunities and challenges as follows:

1. Power

a) Building a workgroup

b) Move employees

c) Supervise

d) Growth in sales results

e) Optimal asset growth

2. Weakness

a) Low ability to make business plans.

b) The ability to establish business relationships is not good.

c) The bargaining power of suppliers in their implementation is anticipated to be unfavorable.

d) The threat of substitution products is not well anticipated.

e) Poor profit growth.

3. Opportunity

a) Local government policy supports the development of the furniture industry

b) The condition of people's purchasing power increases

c) The condition of social status increases

d) The desire to complete home furnishings is increasing

e) Population growth increases

4. Challenge

a) Prepare a good business plan

b) The emergence of new entrants to similar businesses

c) Supplier bargaining power

d) The existence of substitute furniture businesses such as aluminum furniture, rattan, and furniture from coconut trunks.

e) Getting the optimal profit (Source: Field interview with business actors, 2019) 
Based on this information the SWOT analysis can be carried out as follows: Table 8. SWOT Analysis

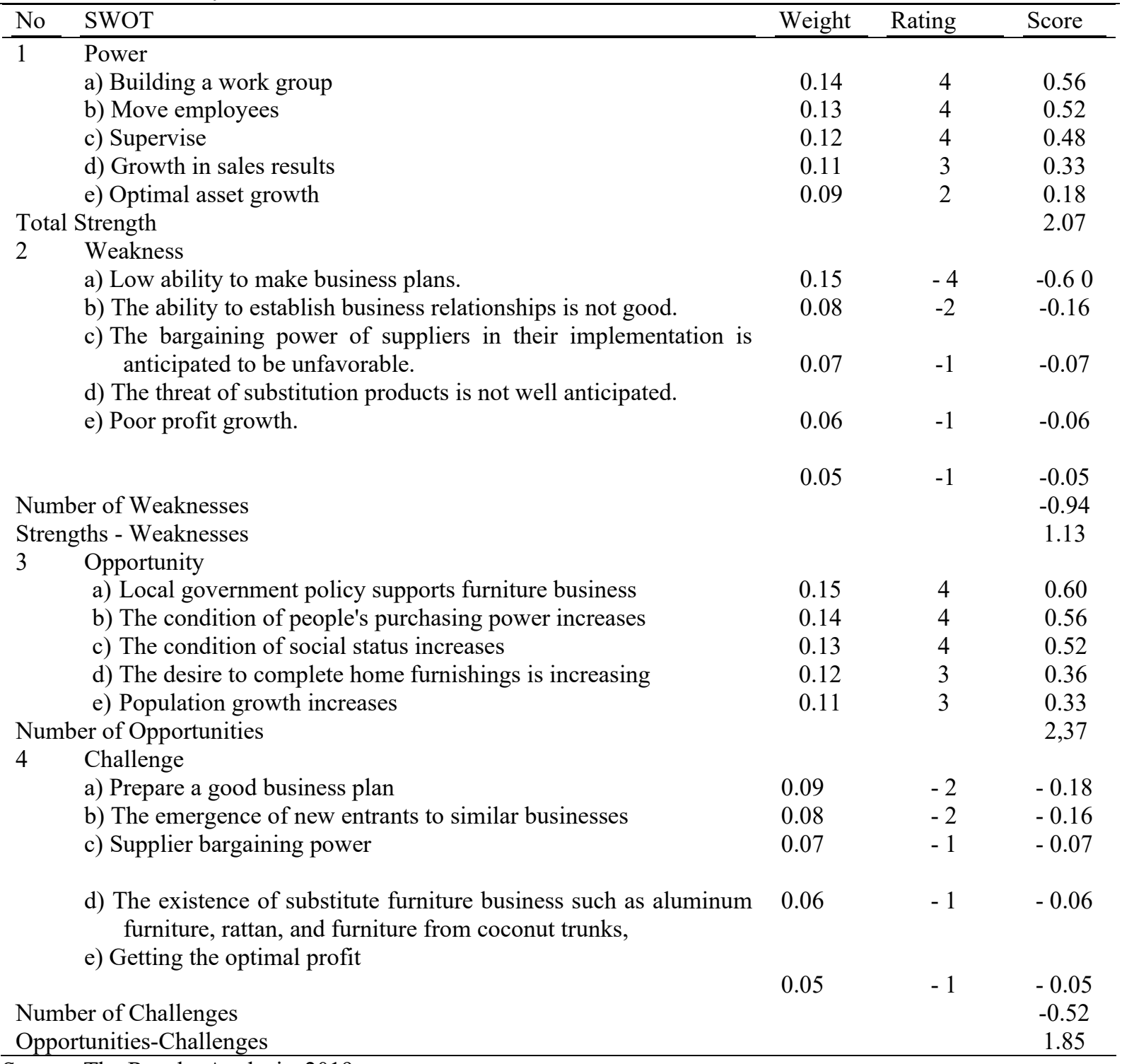

Source: The Results Analysis, 2019

Based on the table is, strategies that can be used to increase the advantage to compete for attempt furniture teak is aggressive growth strategy is to leverage the power of the form of their working groups, mobilizing employees, supervision of work, the growth of sales revenue increased and asset growth are optimized to take advantage of opportunities in the form of their Local government policies support the business of furniture, the condition of people's purchasing power increases, the condition of social status increases, the desire to equip home furnishings increases, population growth increases.

\section{Limitations}

This study has limitations, namely: (1) in the assessment of the weight of the elements of strength, weakness, opportunity, and challenges of teak furniture based on the subjectivity of the importance of these elements. Therefore further research can be developed using interest instruments. (2) The research area is only the teak furniture industry in two cities, namely Konawe Regency and Muna Regency, therefore this research can be developed in other industries (nonteak wood furniture ) in a wider area.

\section{CONCLUSION}

1. Factors causing the teak furniture industry that is not able to develop is due to low ability: (a) making business plans, (b) establishing business relationships, (c) the presence of a supplier bargaining power, (d) Threat of substitute products, (e) growth suboptimal profit.

2. The right model for the development of the teak furniture industry that can create a competitive advantage is 
to use the LIMAPEN model and implement an aggressive growth strategy.

\section{SUGGESTION}

1. For businesses

a) Improve the ability to make business plan, braid business relationships are good competitors, creating partnerships a) with suppliers, including partnerships with the substitution production. Besides increasing profit growth.

b) It is better to increase competitive advantage by using the LIMAPEN model and implementing a competitive advantage strategy.

2. For further researchers:

a) develop this study by using the instrument of the interests of weeks to assess the elements of strengths, weaknesses, opportunities, and challenges

b) Expanding research areas in other industries (nonteak furniture) in a wider area.

\section{REFERENCE}

Adi Permadi, 2015, Strategi Pengembangan Industri Kecil Carica, Journal of Economics and Policy, Universitas Negeri Semarang, Indonesia.

Adytia Suseno dan Ratih Indriyani, 2013, Pengelolaan dan Pengembangan Usaha Furniture pada UD. Ethnic furniture, Jurnal Agora Vol. 1, No. 3, Universitas Kristen Petra, Surabaya.

Alfan Himawan P.,Triwilaswandio,Wuruk Pribadi, 2014, Analisa Teknis dan Ekonomis Pengembangan Industri Pendukung Furnitur Kapal. Jurnal Teknik Pomits Vol. 2, No.1, Institut Teknologi Sepuluh Nopember (ITS), Surabaya.

Barney, Grant, 1991, Firm Resources and Sustained Competitive Advantage, Journal of Management, Vol.17, No. 1

Dendi Anggi Gumilang, Arief Daryanto, Bustanul Arifin, Rudi Wibowo 2014, Analisis Strategi Keunggulan Bersaing dengan Pendekatan Proses Jaringan Kerja Kajian Empiris pada BUMN Perkebunan. Jurnal Manajemen, Volume 18, No. 03 Sekolah Pascasarjana Manajemen dan Bisnis, Institut Pertanian Bogor, Indonesia.

Frans Sudirjo, 2012, Keunggulan Bersaing Berbasis Budaya dan Inovasi Produk: Sebuah Eksplorasi Model Konseptual. JEJAK Journal of Economics and Policy 5(2) Universitas 17 Agustus 1945 (UNTAG) Semarang, Indonesia.

Frans Sudirjo. 2012, Pengembangan Model Membangun Keunggulan Bersaing Berbasis Budaya Pada Industri Meubel Skala Menengah di Jepara. Jurnal Media Ekonomi dan Manajemen Vol. 25. No 1. Universitas 17Agustus 1945 (UNTAG), Semarang.

Hitt, et all. 2001. Manajemen Strategis; Daya Saing dan Globalisasi Konsep. Salemba Empat. Jakarta.

Ida Nuraini, 2013. Potensi dan Model Pengembangan Industri Manufaktur di Kota Malang. Jurnal Gamma, ISSN 2086-3071 Volume 9, No. 1 Universitas Muhammadiyah Malang, Malang.

Khairul Ihwan, Nilda Tri Putri, Jonrinaldi 2015, Usulan Strategi Pengembangan Industri Pengolahan Kelapa Skala IKM di Kabupaten Indragiri Hilir, Jurnal Optimasi Sistem Industri, Vol. 14, No. 2, Universitas Andalas.

Kuncoro Harto Widodo, Kharies Pramudya Dwi Arbita, Aang Abdullah, 2010. Sistem Dinamis Industri Furniture Indonesia Dari Perspektif Supply Chain Management Yang Berkelanjutan, Jurnal Agritech, Vol. 30, No. 2, Universitas Gadjah Mada, Yogyakarta

M. Adhi Prasnowo, Arif Khomaruddin, Khoirul Hidayat 2013. Strategi Pengembangan Sentra Industri Kecil Menengah Produksi Krupuk Teknika: Engineering and Sains Journal, Vol. 1, No.1, Universitas Maarif Hasyim Latif, Sidoarjo, Indonesia

Muhammad Akbar Fatria 2017. Strategi Pengembangan Industri Rumahtangga di Kota Pekanbaru (Studi Kasus Usaha Jamur Crispy Industri Pengolahan Jamur Tiram), Jurnal JOMFekon, Vol.4 No.1, Universitas Riau, Pekanbaru, Indonesia

Nasikh 2010. Model Optimalisasi Faktor Produksi Usaha Industri Kecil Mebel Kayu Jati di Pasuruan Jawa Timur, Jurnal Manajemen dan Kewirausahaan, Vol.11, No.1, Fakultas Ekonomi Universitas Negeri Malang, Malang.

Penrose, E. T. 1959. The Theory of the Growth of the Firm. New York: John Wiley

Sudarti, Sri Budi Cantika Yuli 2017. Strategi Pengembangan Usaha Pengolahan Kerajinan Kayu Jati di Kecamatan Kasiman Kabupaten Bojonegoro Jawa Timur, Jurnal Conference on Management and Behavioral Studies ISSN No: 2541-3406 e-ISSN No: 2541-285X Universitas Tarumanegara, Jakarta

Sugiyono, 2008. Metode Penelitian Kuantitatif Kualitatif, Research and Development. Bandung, Alfabeta.

Teece, D. J et al. 1997. Dynamic Capabilities and Strategic Management. Strategic Management Journal, 18 (7), 509-533.

Trifandi Lasalewo 2012. Faktor-Faktor yang Mempengaruhi Keunggulan Bersaing Industri di Provinsi Gorontalo. Jurnal Teknik dan Manajemen Industri. Vol. 7 No. 1 Universitas Negeri Gorontalo, Kota Gorontalo 